\title{
Production of hydrogen peroxide by
} combination of

semiconductor-photocatalysed

oxidation of water and photocatalytic two-electron reduction of dioxygen

\author{
Yusuke Isaka, Yusuke Yamada, Tomoyoshi Suenobu,
}

Tatsuo Nakagawa and Shunichi Fukuzumi

\begin{tabular}{|c|l|}
\hline Citation & RSC Advances,6(48): 42041-42044 \\
\hline Issue Date & 2016-4-20 \\
\hline Type & Journal Article \\
\hline Textversion & author \\
\hline \multirow{2}{*}{ Rights } & $\begin{array}{l}\text { The following article appeared in RSC Adv., 2016,6, 42041-42044 and may be } \\
\text { found at https://doi.org/10.1039/C6RA06814F . }\end{array}$ \\
& $\begin{array}{l}\text { This is the accepted manuscript version. Please cite only the published version. } \\
\text { 引用の際には出版社版をご確認ご利用ください。 }\end{array}$ \\
\hline DOI & 10.1039/C6RA06814F \\
\hline
\end{tabular}

Self-Archiving by Author(s)

Placed on: Osaka City University

ISAKA, Y., YAMADA, Y., SUENOBU, T., NAKAGAWA, T., \& FUKUZUMI, S. (2016). Production of hydrogen peroxide by combination of semiconductor-photocatalysed oxidation of water and photocatalytic two-electron reduction of dioxygen. RSCAdvances. 6, 42041-42044. 


\section{RSC Advances}

\section{COMMUNICATION}

\section{Production of hydrogen peroxide by combination of semiconductor-photocatalysed oxidation of water and photocatalytic two-electron reduction of dioxygen $\uparrow$}

Received 00th January 20xx, Accepted 00th January 20xx

DOI: $10.1039 / \times 0 \times x 00000 x$

\section{Yusuke Isaka, ${ }^{a}$ Yusuke Yamada, ${ }^{*, b}$ Tomoyoshi Suenobu, ${ }^{a}$ Tatsuo Nakagawa ${ }^{c}$ and Shunichi} Fukuzumi $^{* d, e}$

www.rsc.org/

Production of hydrogen peroxide from water and dioxygen was achieved by combination of semiconductor-photocatalysed oxidation of water and photocatalytic two-electron reduction of dioxygen with $\left[\mathrm{Ru}^{\prime \prime}\left((\mathrm{MeO})_{2} \mathrm{bpy}\right)_{3}\right]^{2+}\left((\mathrm{MeO})_{2}\right.$ bpy $=4,4$ '-dimethoxy2,2'-bipyridine) in the presence of $\mathrm{Sc}^{3+}$ in water under visible light irradiation.

Hydrogen peroxide $\left(\mathrm{H}_{2} \mathrm{O}_{2}\right)$ has attracted considerable interest as a green fuel that can be used in one-compartment fuel cells free of expensive membranes with theoretical maximum output potential of $1.09 \mathrm{~V}$, which is comparable to that of a hydrogen fuel cell $(1.23 \mathrm{~V}){ }^{1-7} \mathrm{H}_{2} \mathrm{O}_{2}$ has also merited increasing attention as a green oxidant, because only water is produced as the reduced product. ${ }^{8-10}$

$\mathrm{H}_{2} \mathrm{O}_{2}$ is currently produced by an industrial process composed of sequential hydrogenation and oxidation of an alkyl anthraquinone, which is not environmentally benign because of many reasons, such as utilisation of toxic solvents, consumption of large amount of energy, and requirement for multiple reaction steps. ${ }^{12,13}$ It is highly desired to produce $\mathrm{H}_{2} \mathrm{O}_{2}$ from water and dioxygen in the air using solar energy.

We have previously reported that $\mathrm{H}_{2} \mathrm{O}_{2}$ can be produced by combination of thermal water oxidation using water oxidation catalysts and photocatalytic two-electron reduction of $\mathrm{O}_{2}$ using $\mathrm{Ru}$ complexes as photocatalysts. ${ }^{14-16}$ When the water oxidation and $\mathrm{O}_{2}$ reduction were performed in a one compartment cell, produced $\mathrm{H}_{2} \mathrm{O}_{2}$ can be decomposed in the presence of water oxidation catalysts to preclude the production of $\mathrm{H}_{2} \mathrm{O}_{2}$ at higher

${ }^{a}$ Department of Material and Life Science, Graduate School of Engineering, Osaka University, ALCA, Japan Science and Technology Agency (JST), Suita, Osaka 565-0871, Japan.E-mail:fukuzumi@chem.eng.osaka-u.ac.jp

${ }^{b}$ Department of Applied Chemistry and Bioengineering, Graduate School of Engineering Osaka City University, Osaka 558-0022, Japan. E-mail: ymd@a-chem.eng.osaka-cu.ac.jp ' Unisoku Co., Ltd, Kasugano 2-4-3, Hirakata, Osaka 573-0131, Japan

${ }^{d}$ Department of Chemistry and Nano Science, Ewha Womans University, Seoul 120-750, Korea

Faculty of Science and Technology, Meijo University, ALCA, Japan Science and Technology Agency (JST), Nagoya, Aichi 468-8502, Japan

Electronic Supplementary Information (ESI) available: Experimental details, 5 Figures [UVVis absorption spectra of solutions and the electrode, schematic representation of a twocompartment cell, phosphorescence spectrum, time course of photocurrent and oxygen generation], estimation of the $\mathrm{O}_{2}$ amount, and calculation of the simulated spectrum. See DOI: $10.1039 / \times 0 \times x 00000 x$ concentrations.

We report herein the photocatalytic production of $\mathrm{H}_{2} \mathrm{O}_{2}$ from $\mathrm{H}_{2} \mathrm{O}$ and $\mathrm{O}_{2}$ using a two-compartment cell composed of a semiconductor photocatalyst anode in one cell and a carbon cloth cathode in the presence of $\mathrm{Ru}$ complexes and $\mathrm{Sc}^{3+}$ in an $\mathrm{O}_{2}$-saturated aqueous solution in the other cell to achieve higher concentrations of $\mathrm{H}_{2} \mathrm{O}_{2}$ as compared with those with a onecompartment cell.

A schematic representation of the two-compartment cell employed in this study is shown in Fig. S2, where $\mathrm{WO}_{3}$ or $\mathrm{BiVO}_{4}$ was used as a photoanode ${ }^{17}$ for photooxidation of water and a carbon mesh cathode was used for photoreduction of $\mathrm{O}_{2}$ by $\mathrm{Ru}$ complexes. The two compartments were separated by a Nafion membrane.

When $\left[\mathrm{Ru}^{\mathrm{II}}\left((\mathrm{MeO})_{2} \mathrm{bpy}\right)_{3}\right]^{2+}\left((\mathrm{MeO})_{2}\right.$ bpy $=4,4^{\prime}$-dimethoxy2,2'-bipyridine, 1) was employed as a photocatalyst for twoelectron reduction of $\mathrm{O}_{2}$ in the presence of $\mathrm{Sc}^{3+}(100 \mathrm{mM})$ in an $\mathrm{O}_{2}$-saturated aqueous solution, photocurrent generation was observed as shown in Fig. 1a, where no or little photocurrent was observed in the absence of $\mathrm{O}_{2} \cdot{ }^{18}$ When $\left[\mathrm{Ru}^{\mathrm{II}}\left((\mathrm{MeO})_{2} \mathrm{bpy}\right)_{3}\right]^{2+}$ was replaced by $\left[\mathrm{Ru}^{\mathrm{II}}\left(\mathrm{Me}_{2} \text { phen }\right)_{3}\right]^{2+}\left(\mathrm{Me}_{2}\right.$ phen = 4,7-dimethyl1,10-phenathroline, 2) under otherwise the same conditions, the photocurrent was significantly smaller by two orders of magnitude (Fig. 1b).

When monochromic light $(\lambda=450 \mathrm{~nm})$ was continuously irradiated to acidic aqueous solutions of $\mathbf{1}$ and $\mathbf{2}$, formation of
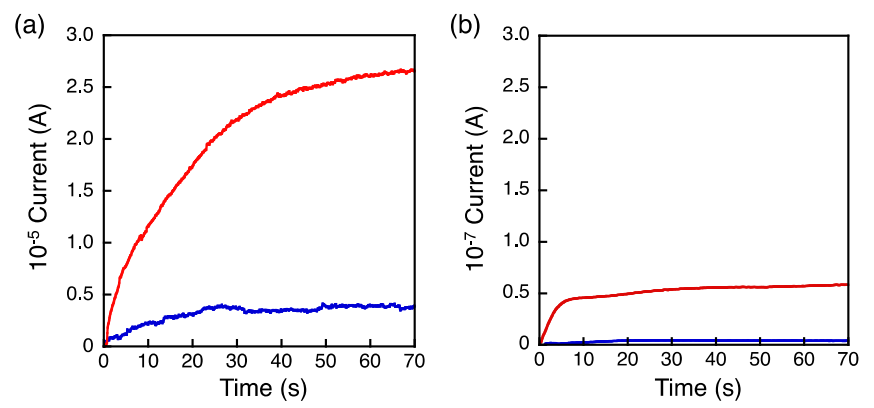

Fig. 1 Photocurrent (at $0.30 \mathrm{~V}$ vs. SCE) under photoirradiation by a Xe lamp $(\lambda>420 \mathrm{~nm})$ of (a) $\left[\mathrm{Ru}^{\prime \prime}\left((\mathrm{MeO})_{2} \mathrm{bpy}_{3}\right]^{2+}(160 \mu \mathrm{M})\right.$ or (b) $\left[\mathrm{Ru}^{\prime \prime}\left(\mathrm{Me}_{2} \text { phen }\right)_{3}\right]^{2+}(160 \mu \mathrm{M})$ in an $\mathrm{O}_{2^{-}}$(red lines) or $\mathrm{N}_{2}$-saturated (blue lines) aqueous solution $(8.0 \mathrm{~mL})$ of $\mathrm{Sc}^{3+}(100 \mathrm{mM})$. 
corresponding $\mathrm{Ru}^{\mathrm{III}}$ complexes was confirmed for both solutions by UV-Vis measurements (Fig. 2). While over $90 \%$ of 1 originally present in the solution existed as $\left[\mathrm{Ru}^{\mathrm{III}}\left((\mathrm{MeO})_{2} \mathrm{bpy}\right)_{3}\right]^{3+}$ after $3500 \mathrm{~s}$ of photoirradiation, only $22 \%$ of 2 was observed as $\left[\mathrm{Ru}^{\mathrm{III}}\left(\mathrm{Me}_{2} \text { phen }\right)_{3}\right]^{3+}$ after light irradiation (Fig. S3). Thus the increased photocurrent observed for $\mathbf{1}$ as compared to $\mathbf{2}$ was due to increased concentration of $\mathrm{Ru}^{\mathrm{III}}$ species in situ that can oxidise

(a)

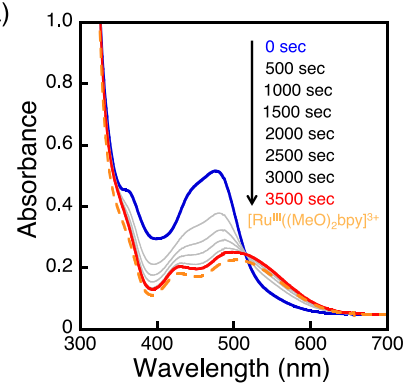

(b)

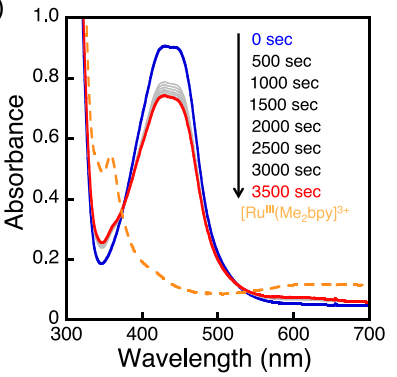

Fig. 2 Changes in the UV-Vis absorption spectrum of an aqueous solution of (a) $\left[\mathrm{Ru}^{\prime \prime}\left((\mathrm{MeO})_{2} \mathrm{bpy}\right)_{3}\right]^{2+}(40 \mu \mathrm{M})$ and (b) $\left[\mathrm{Ru}^{\prime \prime}\left(\mathrm{Me}_{2} \text { phen }\right)_{3}\right]^{2+}(40 \mu \mathrm{M})$ containing $\mathrm{Sc}^{3+}$ (100 mM) under photoirradiation by monochromic light $(\lambda=450 \mathrm{~nm})$. Absorption spectrum of (a) $\left[\mathrm{Ru}^{\prime \prime \prime}\left((\mathrm{MeO})_{2} \mathrm{bpy}\right)_{3}\right]^{3+} \quad(40 \mu \mathrm{M})$ and (b) $\left[\mathrm{Ru}^{\text {III }}\left(\mathrm{Me}_{2} \text { phen }\right)_{3}\right]^{3+}$ in the presence of $\mathrm{Sc}^{3+}(100 \mathrm{mM})$ in water are also shown in the figures (orange lines). $\mathrm{pH}$ of the aqueous solutions are adjusted to $1.0 \mathrm{by}$ $\mathrm{H}_{2} \mathrm{SO}_{4}$ for all of the samples.
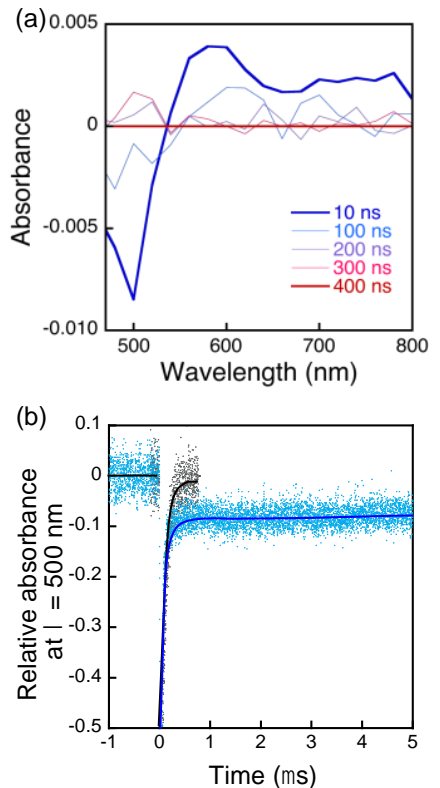

Fig. 3 (a) Transient absorption spectra of $\left[\mathrm{Ru}^{\prime \prime}\left((\mathrm{MeO})_{2} \mathrm{bpy}\right)_{3}\right]^{2+}(20 \mu \mathrm{M})$ in an $\mathrm{O}_{2}$ saturated $\mathrm{H}_{2} \mathrm{O}$ after laser excitation at $\lambda=355 \mathrm{~nm}$. (b) Time profiles of bleachin at $500 \mathrm{~nm}$ due to $\left[\mathrm{Ru}^{\prime \prime \prime}\left((\mathrm{MeO})_{2} \mathrm{bpy}\right)_{3}\right]^{3+}$ in the absence (black line) and presence (blue line) of $\mathrm{Sc}^{3+}(75 \mathrm{mM})$. the electrode to generate photocurrent.

The rate constant of electron transfer from $\left[\mathrm{Ru}^{\mathrm{II}}\left((\mathrm{MeO})_{2} \text { bpy }\right)_{3}\right]^{2+*}$ to $\mathrm{O}_{2}\left(4.9 \times 10^{9} \mathrm{M}^{-1} \mathrm{~s}^{-1}\right)$ was comparable to that from $\left[\mathrm{Ru}^{\mathrm{II}}\left(\mathrm{Me}_{2} \text { phen }\right)_{3}\right]^{2+*}\left(6.1 \times 10^{9} \mathrm{M}^{-1} \mathrm{~s}^{-1}\right)$ where asterisk indicating the photoexcited states of the complexes (Fig. S4) ${ }^{14}$ In the presence of $\mathrm{Sc}^{3+}(100 \mathrm{mM})$, back electron transfer from $\mathrm{O}_{2}{ }^{-}$to $\left[\mathrm{Ru}^{\mathrm{III}}\left((\mathrm{MeO})_{2} \text { bpy }\right)_{3}\right]^{3+}$ examined by nanosecond laser flash photolysis measurements was decelerated significantly due to the strong binding of $\mathrm{Sc}^{3+}$ to $\mathrm{O}_{2}{ }^{-}$as shown in Fig. 3. ${ }^{18}$

When $\mathrm{BiVO}_{4}$ was employed as photocatalyst for the photooxidation of water under visible light irradiation, photocurrent generation as well as $\mathrm{O}_{2}$ evolution was observed (Fig. 4). When $\mathrm{BiVO}_{4}$ was replaced by $\mathrm{WO}_{3}$, the rate of $\mathrm{O}_{2}$ evolution became significantly reduced (Fig. 4b and Fig. S5).

Formation of the hole in the photoexcited $\mathrm{BiVO}_{4}$ was detected around $\lambda=600 \mathrm{~nm}$ as reported previously ${ }^{19}$ by a new technique for subnanosecond transient absorption measurement, RIPT (Randomly-Interleaved-Pulse-Train) method (Fig. 5). ${ }^{20}$ (a)

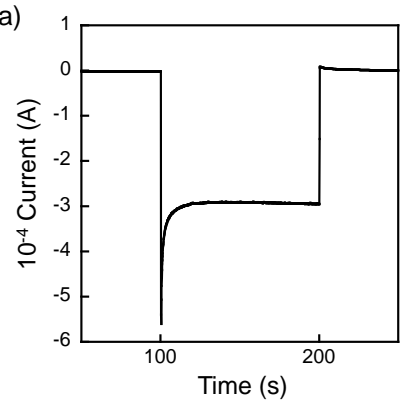

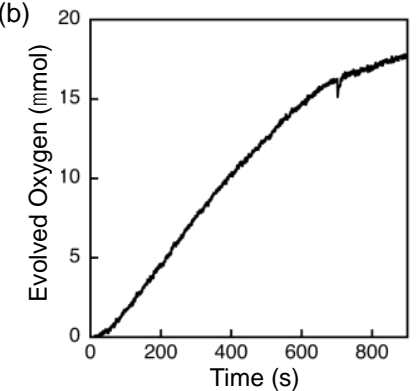

Fig. 4 (a) Photocurrent (at $0.25 \mathrm{~V}$ vs. SCE) under photoirradiation of $\mathrm{BiVO}_{4}$ anode in an aqueous solution of $\mathrm{Sc}\left(\mathrm{NO}_{3}\right)_{3}(100 \mathrm{mM})$ with a Xe lamp $(\lambda>420 \mathrm{~nm})$. (b) $\mathrm{O}_{2}$ evolution during photocurrent generation at an applied potential of $0.52 \mathrm{~V}$ vs SCE measured by using an $\mathrm{O}_{2}$ sensor

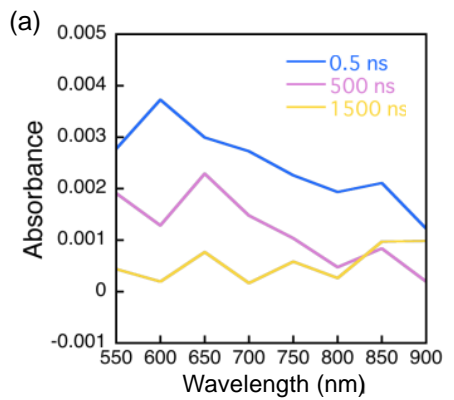

(b)

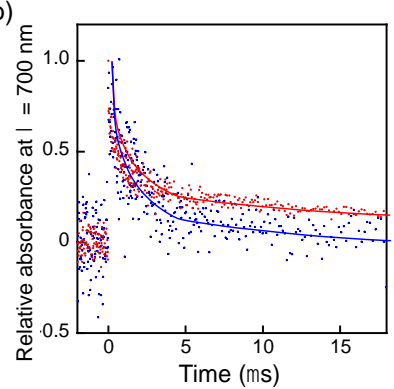

Fig. 5 (a) Transient absorption spectra of photoexcited $\mathrm{BiVO}_{4}$. (b) Absorbance at $\lambda=700$ $\mathrm{nm}$ relative to absorbance at $0 \mu$ s without bias voltage (blue line) and at $0.5 \mathrm{~V}$ vs. SCE (red line). 


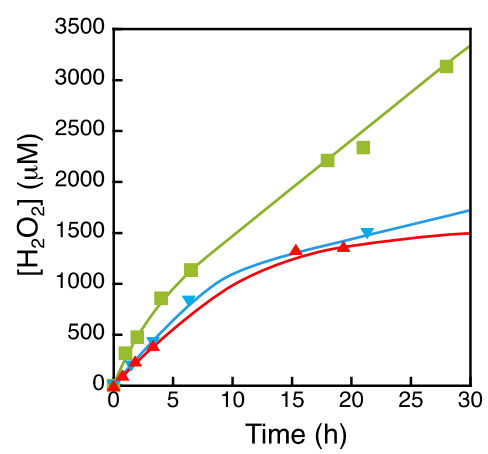

Fig. 6 Production of $\mathrm{H}_{2} \mathrm{O}_{2}$ under photoirradiation of a two-compartment cell composed of a semiconductor photocatalyst anode $\left(\mathrm{BiVO}_{4}\right.$ (green line and blue line) or $\mathrm{WO}_{3}$ (red line)) in one cell and a carbon cloth cathode in the presence of $\left[\mathrm{Ru}^{\prime \prime}\left((\mathrm{MeO})_{2} \mathrm{bpy}\right)_{3}\right]^{2+}$ (160 $\mu \mathrm{M}$, black line) or [Ru"(Me $\mathrm{R}_{2}$ phen $\left.)_{3}\right]^{2+}(160 \mu \mathrm{M}$, blue line and green line) in the other cell. Both cells were filled with aqueous solution of $\mathrm{Sc}^{3+}(100 \mathrm{mM}, 8.0 \mathrm{~mL}$ for each cell). A Xe lamp $(\lambda>420 \mathrm{~nm})$ and a solar simulator were used to irradiate Ru complex and semiconductor photocatalyst, respectively.

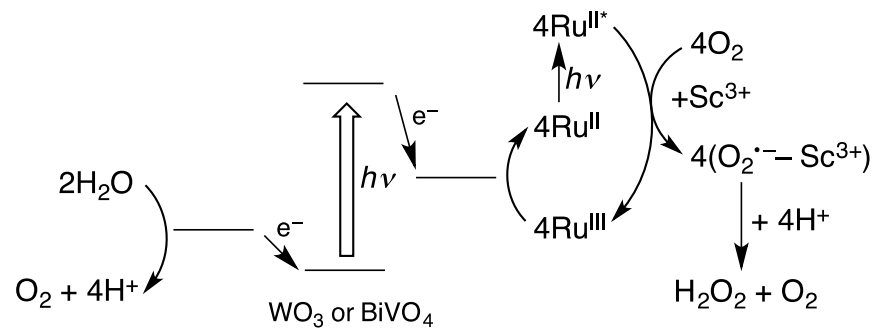

Scheme 1. Catalytic cycle of the photocatalytic production of $\mathrm{H}_{2} \mathrm{O}_{2}$ from $\mathrm{H}_{2} \mathrm{O}$ and $\mathrm{O}_{2}$ using a $\mathrm{Ru}$ photocatalyst and a semiconductor photocatalyst. $\mathrm{Ru}^{\prime \prime *}$ and $\mathrm{O}_{2}{ }^{--}$indicate photoexcited state of Ru" complex and superoxide radical anion, respectively.

The lifetime of the observed hole was elongated when a positive voltage was applied to the electrode possibly because recombination of electrons and holes was retarded by accelerated consumption of electrons at electrode (Fig. 5b).

The combination of the $\mathrm{BiVO}_{4}$ photoanode and carbon mesh cathode in the presence of $\left[\mathrm{Ru}^{\mathrm{II}}\left((\mathrm{MeO})_{2} \mathrm{bpy}\right)_{3}\right]^{2+}$ and $\mathrm{Sc}^{3+}$ gave the best performance in terms of the photocatalytic production of $\mathrm{H}_{2} \mathrm{O}_{2}$ from $\mathrm{H}_{2} \mathrm{O}$ and $\mathrm{O}_{2}$ as shown in Fig. 6 .

Based on above-mentioned results, the photocatalytic production of $\mathrm{H}_{2} \mathrm{O}_{2}$ from $\mathrm{H}_{2} \mathrm{O}$ and $\mathrm{O}_{2}$ is summarised in Scheme 1. Electron transfer from $\left[\mathrm{Ru}^{\mathrm{II}}\left((\mathrm{MeO})_{2} \text { bpy }\right)_{3}\right]^{2+*}$ to $\mathrm{O}_{2}$ occurs to produce $\left[\mathrm{Ru}^{\mathrm{III}}\left((\mathrm{MeO})_{2} \mathrm{bpy}\right)_{3}\right]^{3+}$ and $\mathrm{O}_{2}{ }^{-}$. Strong biding of $\mathrm{Sc}^{3+}$ to $\mathrm{O}_{2}^{-}$to give $\mathrm{O}_{2}{ }^{--}-\mathrm{Sc}^{3+}$ complex prohibits back electron transfer from the $\mathrm{O}_{2}{ }^{--}-\mathrm{Sc}^{3+}$ complex to $\left[\mathrm{Ru}^{\mathrm{III}}\left((\mathrm{MeO})_{2} \mathrm{bpy}\right)_{3}\right]^{3+}$. The $\mathrm{O}_{2}{ }^{-}-\mathrm{Sc}^{3+}$ complex disproportionates in the presence of $\mathrm{H}^{+}$ to produce $\mathrm{H}_{2} \mathrm{O}_{2}$. On the other hand, the photoexcitation of $\mathrm{BiVO}_{4}$ results in formation of holes that oxidise water to $\mathrm{O}_{2}$. Electrons in conduction band of $\mathrm{BiVO}_{4}$ reduce $\left[\mathrm{Ru}^{\mathrm{III}}\left((\mathrm{MeO})_{2} \mathrm{bpy}\right)_{3}\right]^{3+}$ to regenerate $\left[\mathrm{Ru}^{\mathrm{II}}\left((\mathrm{MeO})_{2} \mathrm{bpy}\right)_{3}\right]^{2+}$.

In conclusion, $\mathrm{H}_{2} \mathrm{O}_{2}$ was produced from water and dioxygen by combination of $\mathrm{BiVO}_{4}$-phoocatalysed oxidation of water and photocatalytic two-electron reduction of dioxygen with $\left[\mathrm{Ru}^{\mathrm{II}}\left((\mathrm{MeO})_{2} \mathrm{bpy}\right)_{3}\right]^{2+}$ in the presence of $\mathrm{Sc}^{3+}$ in water using a two-compartment cell under visible light irradiation. This study provides a promising way for production of $\mathrm{H}_{2} \mathrm{O}_{2}$ as a solar fuel.
The further improvement of the catalytic activity and stability is now in progress.

\section{Acknowledgements}

This work was supported by ALCA and SENTAN (Development of Systems and Technology for Advanced Measurement and Analysis) programs of Japan Science and Technology Agency (JST), Japan. We thank Mr. Kido Okamoto, Unisoku Co., Ltd., for the setup of the RIPT instrument with our electrodes.

\section{Notes and references}

1 (a) S. Fukuzumi, Y. Yamada and K. D. Karlin, Electrochim. Acta, 2012, 82, 493-511; (b) S. Fukuzumi and Y. Yamada, Aust. J. Chem., 2014, 67, 354-364; (c) S. Fukuzumi, Biochim. Biophys. Acta, 2016, in press.

2 L. An, T. Zhao, X. Yan, X. Zhou and P. Tan, Science Bull., 2015, 60, 55-64.

3 (a) S. Yamazaki, Z. Siroma, H. Senoh, T. Ioroi, N. Fujiwara and K. Yasuda, J. Power Sources, 2008, 178, 20-25; (b) Y. Yamada, Y. Fukunishi, S. Yamazaki and S. Fukuzumi, Chem. Commun., 2010, 46, 7334-7336; (c) Y. Yamada, S. Yoshida, T. Honda and S. Fukuzumi, Energy Environ. Sci., 2011, 4, 2822-2825.

4 (a) S. A. M. Shaegh, N. T. Nguyen, S. M. M. Ehteshami and S. H. A. Chan, Energy Environ. Sci., 2012, 5, 8225-8228; (b) Y. Yamada, M. Yoneda and S. Fukuzumi, Chem.-Eur. J., 2013, 19, 11733-11741; (c) Y. Yamada, M. Yoneda and S. Fukuzumi, Inorg. Chem., 2014, 53, 1272-1274.

5 (a) F. Yang, K. Cheng, T. Wu, Y. Zhang, J. Yin, G. Wang, and D. Cao, RSC Adv., 2013, 3, 5483-5490; (b) F. Yang, K. Cheng, X. Xiao, J. Yin, G. Wang and D. Cao, J. Power Sources, 2014, 245, 89-94; (c) X. Xiao, F. Yang, K. Cheng, X. Wang, J. Yin and K. Ye, J. Electroanal. Chem., 2014, 729, 103-108.

6 Y. Yamada, M. Yoneda and S. Fukuzumi, Energy Environ. Sci., 2015, 8, 1698-1701.

7 B. Reuillard, S. Gentil, M. Carrière, A. L. Goff and S. Cosnier, Chem. Sci., 2015, 6, 5139-5143.

8 (a) A. Fingerhut, O. V. Serdyuk and S. B. Tsogoeva, Green Chem., 2015, 17, 2042-2058; (b) C. Wang and H. Yamamoto, Chem.-Asian J., 2015, 10, 2056-2068.

9 O. Cusso, X. Ribas and M. Costas, Chem. Commun., 2015, 51 , 14285-14298.

10 P. Saisaha, J. W. de Boer and W. R. Browne, Chem. Soc. Rev., 2013, 42, 2059-2074.

11 Y. Zhu, Q. Wang, R. G. Cornwall and Y. Shi, Chem. Rev., 2014, 114, 8199-8256.

12 J. M. Campos-Martin, G. Blanco-Brieva and J. L. Fierro, Angew. Chem., Int. Ed. 2006, 45, 6962-6984.

13 C. Samanta, Appl. Catal., A: Gen. 2008, 350, 133.

14 S. Kato, J. Jung, T. Suenobu and S. Fukuzumi, Energy Environ. Sci., 2013, 6, 3756-3764.

15 Y. Isaka, S. Kato, D. Hong, T. Suenobu, Y. Yamada and S. Fukuzumi, J. Mater. Chem. A, 2015, 3, 12404-12412. 
16 Y. Isaka, K. Oyama, Y. Yamada, T. Suenobu and S. Fukuzumi, Catal. Sci. Technol., 2016, 6, 681-684.

17 (a) P. Xu, J. Feng, T. Fang, X. Zhao, Z. Li and Z. Zou, RSC $A d v ., 2016$, 6, 9905-9910; (b) Y. Park, K. J. McDonald and K.-S. Choi, Chem. Soc. Rev., 2013, 42, 2321-2337.

18 M. K. Nazeeruddin, S. M. Zakeeruddin and K. Kalyanasundaram, J. Phys. Chem. 1993, 97, 9607-9612.

19 Y. Ma, S. R. Pendlebury, A. Reynal, F. L. Formal and J. R. Durrant, Chem. Sci. 2014, 5, 2964-2973.

20 T. Nakagawa, K. Okamoto, H. Hanada and R. Katoh, Opt. Lett., 2016, 41, 1498-1501. 